\title{
Exploring Childhood Statelessness in South Africa
}

F Khan*

\section{P.E.R}

Pioneer in peer-reviewed, open access online law publications

Author

Fatima Khan

Affiliation

University of Cape Town

South Africa

Email fatima.khan@uct.ac.za

Date Submission

29 May 2019

Date Revised

5 March 2020

Date Accepted

5 March 2020

Date published

4 May 2020

Editor Dr G Viljoen

How to cite this article

Khan F "Exploring Childhood

Statelessness in South $1 \mathrm{rlt}$ / PELJ 2020(23) - DO http://dx.doi.org/10.1715s, 7273781/2020/v23i0a6414

\section{Copyright}

(c)

DOI

http://dx.doi.org/10.17159/1727-

3781/2020/v23i0a6414

\section{Abstract}

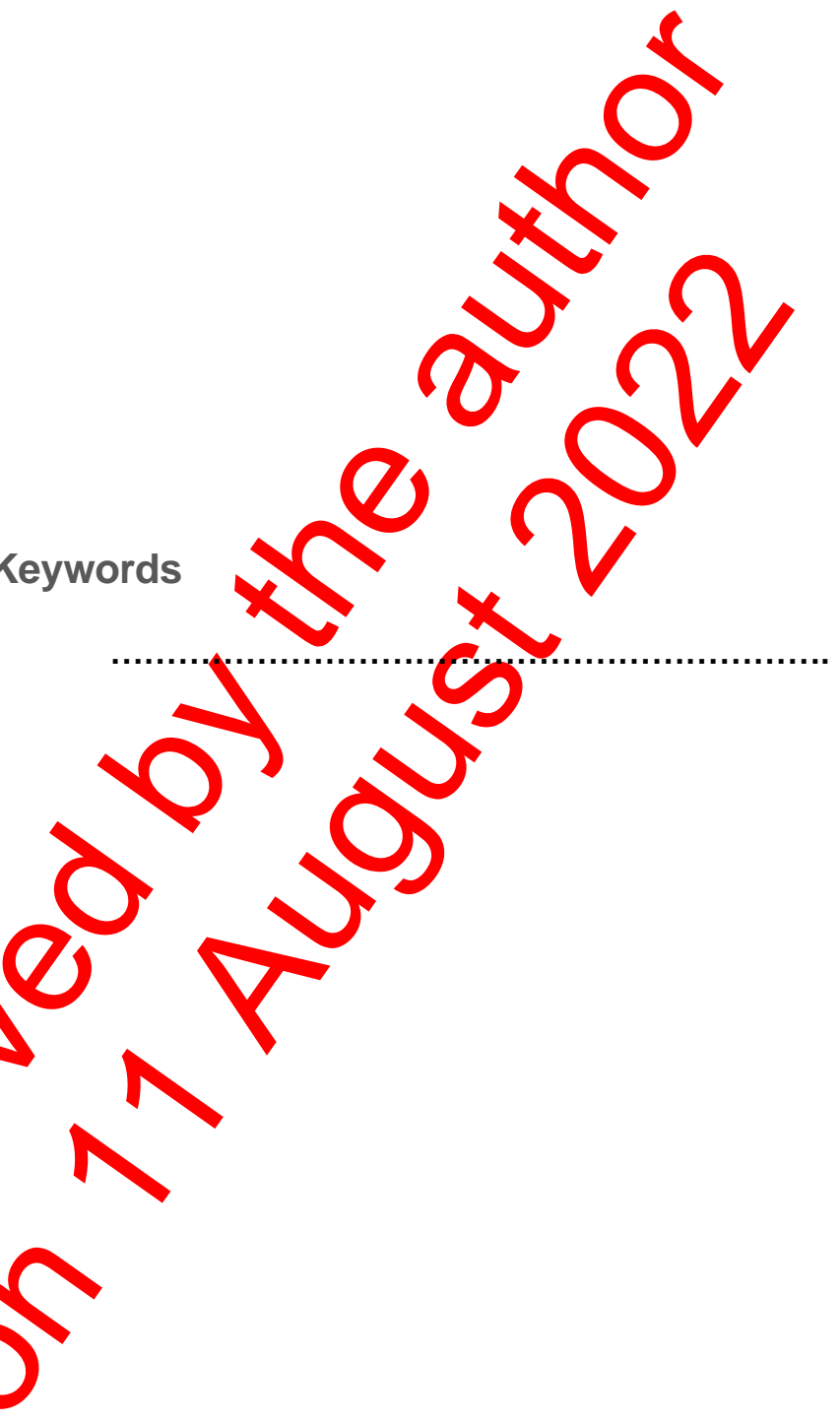

Keywords 